\title{
POU1F1 Gene
}

National Cancer Institute

\section{Source}

National Cancer Institute. POU1F1 Gene. NCI Thesaurus. Code C133844.

This gene is involved in the regulation of genes associated with pituitary development. 